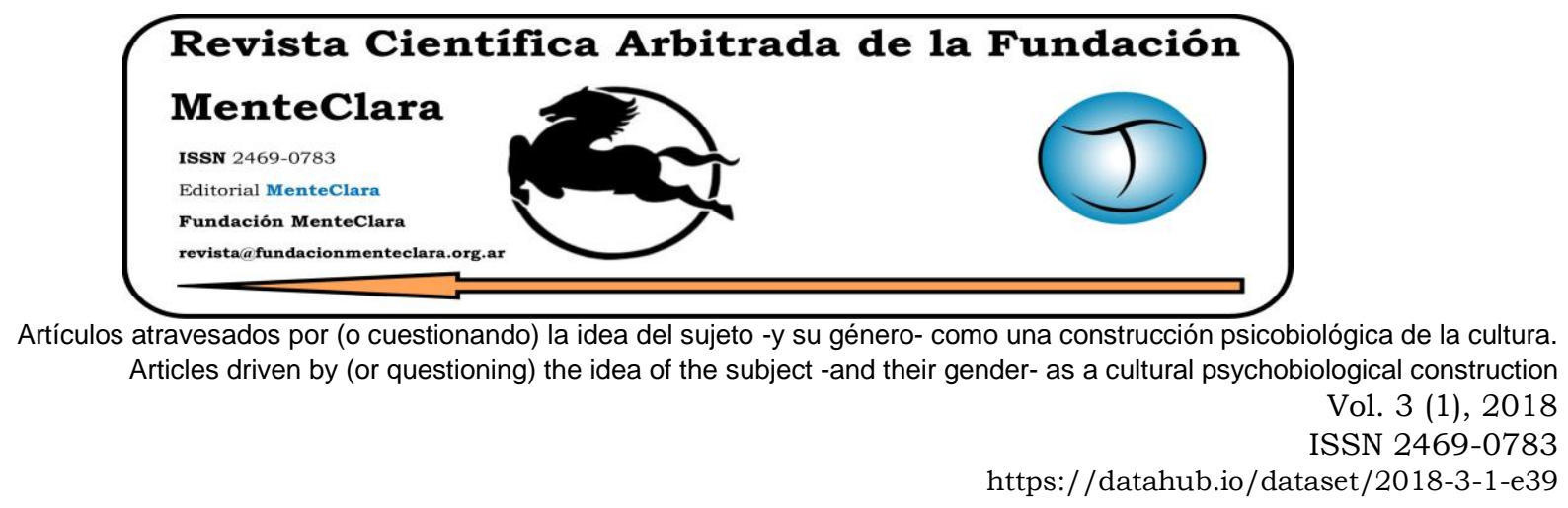

\title{
DALITS, INTERNET AND EMANCIPATORY POLITICS
}

\author{
DALITS, INTERNET Y POLÍTICAS EMANCIPADORAS
}

Shraddha Kumbhojkar shraddha@unipune.ac.in

Savitribai Phule Pune University, History, Faculty Member

Citation: Kumbhojkar S. (2018). "Dalits, Internet and Emancipatory Politics". Revista Científica Arbitrada de la Fundación MenteClara, 3(1), 45-56.

DOI: $10.32351 /$ rca.v3.1.42

Copyright: (C) 2018 RCAFMC. Este artículo de acceso abierto es distribuido bajo los términos de la licencia Creative Commons Attribution-Non Commercial (by-cn) Spain 3.0. Aceptado: 23/04/2018 Publicación online: 30/4/2018

Conflict of interests: None to declare.

\begin{abstract}
The paper argues that Dalits in Maharashtra have learnt to make use of the internet in support of their emancipatory politics to voice their concerns about inequality, document instances of unfair treatment, rally together for a common cause, and share their successes and failures in their fight for equality. They have been able to exercise their agency in their use of the internet and have effectively used it to assert their ideas and voices. A large chunk of the Dalit population is definitely on the wrong side of the digital divide. However, a review of the various creative ways in which the Dalits have used the internet helps us paint a picture of resistance, a picture of hope and also of melancholy. The internet has been used by the Dalits in Maharashtra as an emancipatory space. With the help of the internet, they are getting access to authentic sources of information and an audience with a genuine interest in their stories. The internet helps them document their own history through their own gaze by bringing people together, protected by the comparative anonymity of cyberspace. There is a slow but steady transition from a universe of Grand Narratives of Dalit history to a multiverse of competing memories and histories taking shape.
\end{abstract}

\section{Resumen}

El documento argumenta que los dalits en Maharashtra han aprendido a usar Internet para apoyar sus politicas emancipadoras, para expresar sus preocupaciones sobre la desigualdad, documentar instancias de trato injusto, reunirse para una causa común y compartir sus éxitos y fracasos en su lucha por igualdad. Ellos han 
podido ejercer su capacidad para usar Internet y la han utilizado efectivamente para hacer valer sus ideas y voces. Una gran parte de la población dalit está definitivamente en el lado equivocado de la brecha digital, sin embargo, una revisión de las diversas formas creativas en que los dalit han usado internet nos ayuda a pintar un cuadro de resistencia, una imagen de esperanza y también de melancolía. Internet ha sido utilizado por los dalits en Maharashtra como un espacio emancipatorio. Con la ayuda de Internet, obtienen acceso a fuentes de información auténticas y a una audiencia con un interés genuino en sus historias. Internet les ayuda a documentar su propia historia a través de su propia mirada reuniendo a las personas, protegidas por el anonimato comparativo del ciberespacio. Hay una transición lenta pero constante desde un universo de Grandes Narrativas de la historia Dalit a un multiverso de historias e historias en competencia tomando forma.

\section{Keywords}

Caste; Dalit; Internet; Social Media; Emancipation; Western India; Contemporary History; Casta; Medios de comunicación social; Emancipación; India occidental; Historia contemporánea 


\section{Introduction}

Voltaire, writing in 1764, remarked on the constructed and contested nature of historical narratives. "All ancient histories, as one of our wits has observed, are only fables that men have agreed to admit as true. With regard to modern history, it is a mere chaos, a confusion which it is impossible to make anything of." 1 Voltaire's remark is as much about the conspiracy of consent regarding the constructed nature of ancient history, as it is about the uncontrollable and contested nature of modern historical narratives. If one applies his words to the case of Maharashtrian Dalit ${ }^{2}$ narratives of history, it becomes evident that historical narratives about a distant past are, indeed, traditionally monopolized by the powers that be. However, in the case of the recent past, more and more voices are being heard, though some may be deemed as 'mere chaos'.

\section{Historical Background:}

When the Indian Nation was being ideologically constructed in the nineteenth and the twentieth century, it was realized that caste is a major obstacle that thwarts the road to a unanimous vision of the Indian Nation. Indian National Congress and its leaders tended to believe that in the struggle between the colonizers and the colonized; caste really is an inconvenient nuisance which needs to be quickly forgotten. While for Dr. Ambedkar, the leader who represented the multitudes that faced discrimination, caste was a systemic problem. Without achieving Fraternity and Equality, he believed that Liberty or political freedom was meaningless. On this background, on 14th August 1931, Dr. Ambedkar famously argued, "Mr. Gandhi, I have no Homeland."

Dr. Ambedkar drew out a clear agenda for creating an identity for the Dalits on a clean slate. He did not approve of the Gandhian nomenclature of Harijan for the Dalits, nor did he want them to be known by their castes. Hence the word Dalit that underlined the identity of oppression was chosen by Dr. Ambedkar and his followers to identify themselves. In 1956, Dr. Ambedkar chose to become Buddhist and millions of his admirers followed suit. The idea was to create a new collective and individual identity for the Dalits that would have no affinity with the caste hierarchy implicit in Hinduism. Before the new identity could be reinforced on the public mind, however, Dr. Ambedkar passed away. The mantle has since been carried by a collective leadership of the Dalits. This absence of a singular figure of authority perhaps accounts for the variety of manifestations of the collective identity of Ambedkarite Dalits. Especially in Maharashtra, they have helped evolve a collective identity and culture which is not fixed to their political affiliation. 
History and traditions have been harnessed for legitimizing the Dalits' lowly status and consequently, it has been very important for the Dalit publics to search for a counter-historiographical tradition. Major revolts against caste oppression and other inequalities in Indian history seem to have used a two-pronged strategy: first, claiming the authority to write independent historical narratives from one's own point of view, and second, discrediting the grand narratives constructed by those in power. Thinkers starting from Buddha made efforts to effectively communicate the ideals of equality and social justice both to the oppressors and the oppressed. Charvaka's (before 500 C. E.) criticism $^{3}$ of the creators of the Vedic literature or Tukarama's (17th century) claim 4 that ' $w e$ are the only ones who truly understand the meaning of the Vedas'. These were manifestations of the thinker's efforts to discredit the grand narratives and claim the authority to ascribe meaning to the scriptures. The modern period of history also saw efforts such as the Satya Shodhak Samaj (Society of Truth Seekers established by Jotirao Phule in 1873), which attempted to offer an alternative cultural narrative that exonerated the lower castes from the responsibility of their plight ${ }^{5}$.

\section{Argument:}

All these efforts can be seen as attempts to claim the agency to historicize one's own past. In the nineteenth and the twentieth century, thinkers such as Phule and Ambedkar used the print media for sharing their emancipatory counter-historiographies with the Dalit publics. Twenty- first century Maharashtra has seen the communication revolution and a concomitant democratization of knowledge. It is argued here, that Dalits in twenty-first century Maharashtra are creatively using the Internet as an emancipatory space. They may not be able to fully utilize the potential of the internet, nor are they working in an organized and uni-directional manner. However, a review of their activities in cyberspace attests to the fact that just like Gutenberg's revolution, the Internet is acting as a catalyst in a number of inter-connected phenomena that are useful for Dalit emancipation.

A technocrat at a world summit of the G-8 nations in 2011 thus described the potential of the internet for the disadvantaged people.

"The critical change produced by the digital network environment is the radical decentralization of the capacity to speak, to create, to innovate, to see together, to socialize, the radical distribution of the poor means of production, computations, communications...that which gets us together inside the experience, being there on the ground"6. 
This ability to share things as they happen is a remarkable thing for any society. For the people who have been historically deprived of the agency to tell their own story, the importance of the internet and the opportunities it offers for networking with fellow human beings cannot be overemphasized. Maharashtrian Dalit youth have definitely taken to the internet in the last few years. That the figures of internet penetration among the Indian population have been growing at a breathtaking speed, is no secret ${ }^{7}$. However, specific caste-wise data of network usage or connectivity are not available. In such a scenario, case studies become an important tool of understanding how the internet is used by the Dalits, who have been deprived of opportunities to create and share knowledge.

What is worth the attention of researchers of Maharashtrian place and space is perhaps the fact that the Dalit youth in Maharashtra are increasingly making use of the internet as a space that offers emancipatory opportunities. The present paper argues that Dalits in Maharashtra have learnt to make use of the internet in support of their emancipatory politics. More than any public space that is physically identifiable; the Dalits in Maharashtra are comfortably making use of the internet to voice their concerns about inequality, document instances of unfair treatment, and rally together for a common cause and share their successes and failures in their fight for equality. This is not to say that by virtue of the huge potential of the internet the Dalits have successfully achieved what they want. Far from it. However, the fight for equality would have been much less visible and much less effective, had the Maharashtrian Dalits not been able to use the internet as effectively as they do. What an African journalist has said in her local context can be relevant in this case, too. She says that 'the mere presence of women in online spaces does not constitute emancipation unless they can exercise agency and use those spaces to assert themselves ${ }^{8}$.' Similarly, Dalits in Maharashtra, it is argued here, have been able to exercise their agency in their use of the internet and have effectively used it to assert their ideas and voices. A large chunk of the Dalit population even today is definitely on the wrong side of the digital divide. However, a review of the various creative ways in which the Dalits have used the internet helps us paint a picture of resistance, a picture of hope and also of melancholy.

\section{Discussion:}

Beyond a few web-pages that have largely gone un-archived, source materials relevant for Dalit emancipation began to appear online in the year 2000. This was also the year when the International Dalit Solidarity Network was established. From 2001 onwards, Dr. Ambedkar's speeches 
reported in The Hindu, a daily newspaper, back in 1951 found their way into the online edition of the newspaper, which was indexed and archived by Francis Pritchet in his pages on the website of the Columbia University ${ }^{9}$. Though these were not direct contributions by Maharashtrian Dalit people, they have proved to be important for the emancipation movement as widely used source materials to date. A Maharashtrian Dalit engineer had begun the work of Dalit emancipation and solidarity from a different location a few years before this. The first ever Dalit International Conference was organized through the Dalit International Organization, Malaysia (DIO) in October 1998 in Kuala Lumpur by Mr Rajkumar Kamble and his colleagues ${ }^{10}$. While the internet may not have been used for organizing the conference, its documentation has been preserved with the help of the internet. After 20 odd years, the pamphlets and the photographs of the conference are preserved on the website of the organization that bloomed from the conference, Dr. Ambedkar International Mission (AIM). The AIM has not only organized a number of follow up conventions of Dalits in Paris and the U.S., it has also been instrumental in organizing a Conference at Columbia University, USA in 2013 to commemorate Dr. Ambedkar's arrival there a hundred years before.

Around 2008, the internet began to be effectively used as a medium to achieve what the Truth and Reconciliation Commissions were able to achieve in the Western world. In September 2006, members of a Dalit family were abducted, raped and killed in village Khairlanji, eastern Maharashtra, with no witnesses ready to testify. Mainstream media did not report the news for weeks together. A Dalit government officer used the potential of the internet by publicly uploading the report of the Fact Finding Commission that documented the findings about the crime ${ }^{11}$. This was quickly taken down from the website, but by then it had been widely shared and reported in the mainstream media. Whether the action helped secure justice for the sole surviving member of the family is a different issue, but the internet was usefully harnessed to at least give voice to an otherwise voiceless victim.

The arrival of YouTube and Facebook in India are two phenomena that gave a further boost to the idea of using the internet specifically for purposes relevant to the Dalit people. Dalit music had always been very popular in Maharashtra. In fact, a Marathi saying, though perpetuating caste-based labels, acknowledges that Brahmin households have writing and Mahar households have music ${ }^{12}$. The YouTube videos of Ambedkarite songs are some of the most viewed videos in the world of Marathi music. Non-Bollywood Ambedkarite songs by the famous family - Anand, Milind and Adarsh Shinde- have easily garnered more than a million views 
each $^{13}$. Dalit Camera is a popular YouTube channel operating since 2007 that has more than 6 million views for its videos, films and documentations relevant to the Dalit lives ${ }^{14}$. A number of films pertaining to the issues that the Dalits are interested in are easily available and widely shared on YouTube. There are films featuring Dr Ambedkar's speeches, his funeral procession, clips of Dalit leaders' speeches, episodes of television series such as Samvidhan which dealt with the making of the Indian Constitution and even videos of untoward incidents such as the riots in early 2018 at Bheema Koregaon filmed and shared by the members of the public. Facebook also is a very popular medium for bringing about Dalit solidarity.

Facebook became popular in India over the second decade of the twenty-first century as the number of smart-phone users went up. In 2013, the number of active mobile phone Facebook users in India was 57.5 million and is expected to reach 167.7 million users in $2018{ }^{15}$. WhatsApp, which is a popular internet-based messaging application for smartphone users, has also been bought by Facebook. Both Facebook and WhatsApp, have opened unimagined new vistas for the Dalits who wish to come together or share any ideas while enjoying the anonymity of the social network. There are dozens of Facebook pages related to the Ambedkarite movement and managed by Maharashtrian Dalit youth. Vaibhav Chhaya ${ }^{16}$ is a Dalit activist and media professional who has been organizing a festival to commemorate the Dalit poet Namdeo Dhasal. The festival entitled, 'Sarva Kahi Samashtisathi', has been popularised with the help of his Facebook page. The schedule of the festival, changes to and details of the programme are shared on the Facebook page.

In times of crisis, too, the internet technology and the power of Facebook has shown that it can be harnessed for larger good. On 6th December 2017, when hundreds of thousands of Ambedkarites began to gather in Chaitya Bhoomi in Mumbai to pay annual homage to Dr Ambedkar, Vaibhav Chhaya and dozens of Dalit activists realized that there was a cyclone warning sent out for Mumbai. With the help of Facebook and WhatsApp, they organized tons of food to be cooked by friends and families, and distributed throughout designated places in Mumbai where thousands of Ambedkarites had to take shelter for a couple of days. Another Facebook group called the Facebook Ambedkarite Movement (FAM) has more than 50,000 members. It gave a call for Ambedkar's followers that they should save the money they otherwise spend on garlands for Ambedkar's statue and make a small donation of one notebook and one pen to be used for distribution among the 
Ambedkarite students that gather for various rallies. The idea became really popular over the last three years and this year, that is in 2018 , the movement was responsible for distributing 2,00,000 notebooks for the needy students ${ }^{17}$.

Besides the social network part, where one can easily organize likeminded people without too much of fear of caste labeling, the internet has proven useful for fearlessly presenting Dalit viewpoints about almost anything. In 2014, a new edition of Dr Ambedkar's Annihilation of Caste with an introduction by Arundhati Roy was published. Many Dalit activists found that Roy's introduction did not convey what Dr Ambedkar wanted, and they felt that in fact her introduction was unfairly taking the readers' attention away from Dr. Ambedkar's essential argument. A number of Dalit scholars and thinkers as a part of the Ambedkar Age Collective wrote their repartees around the theme and even published a book called 'Hatred in the Belly' as an 'answer back' to Roy's arguments. Gaurav Somvamshi is a part of this collective, which is associated with the website called roundtableindia.co.in. He is one of the authors who have, while pursuing their independent careers, taken up issues of caste inequality and its justification. He wrote a seven-part article on http://roundtableindia.co.in/, which dealt with the various questions that he faced as a Dalit in the present day ${ }^{18}$. The articles garnered a lot of views and discussion through the website as well as through his personal Facebook page. This is a case that goes to show that social media and websites can go hand in hand or complement the content that each of them have got.

WhatsApp is an application that lets users share digital media in a closed group setting. Umesh Hattikat is a research student who has recently submitted his $M$. Phil. dissertation that studies the history of the Vhalar subcaste. This is a subcaste that is found scattered in South Maharashtra and has a very low literacy rate. When Hattikat set out to study the caste group, he was not sure how he could get information regarding the recent history of the Vhalar people. However, to his surprise, he found that the Vhalar youth had organized themselves in a caste group via WhatsApp and were all approachable through that messaging service. His survey work became very easy after this discovery, and he hopes the dissertation will have some policy implications for eventually bettering the lives of the Vhalar community members ${ }^{19}$.

Dalit literature was once accused of lacking a sense of humour ${ }^{20}$. Today, the accusation can no longer stand. In the early phase of autobiographical and cathartic writings, Dalit literature paid little 
attention to humour as a genre, though dark humour has always been present in the writings of Maharashtrian Dalit authors such as Baby Kamble $^{21}$. With the availability of visual editing tools coupled with smartphones and computers, memes have become a very popular form of presenting one's viewpoint in a humour fashion. Typically memes contain images decorated with comments. Dalit youth have launched Facebook pages that regularly upload relevant and topical memes that use satire. Just Savarna Things, Savarna Fat Cat, Sassy Bahujan Memes are a few of them ${ }^{22}$.

The examples dealt with so far have primarily shown how the internet has helped Maharashtrian Dalits in exploring ways to emancipate themselves. The story obviously has a grim side, too. A Dalit smartphone user was murdered in Shirdi over an altercation regarding his use of an Ambedkarite song as his ringtone in 201523. This is by no means a solitary instance. The Bheema Koregaon riots in the New Year week of 2018 also had a strong relationship with the content spread through the social media. Competing and contradictory narratives of history were floated by the Dalits as well as non-Dalits in the build-up to the event which commemorated the battle of Bheema Koregaon that took place 200 years ago. Videos were virally circulated with the aim of fanning communal hatred and they resulted in loss of at least one life and property worth millions of rupees. Present day contestations for social acceptance are almost always played out in the field of historical narratives. The Bheema Koregaon riots were no exception.

Beyond physical violence, ideological violence is also a very real threat to the Dalit movement. A number of activists have expressed the apprehension that the internet, like most media technologies, tends to limit the manifestations of solidarity or dissent to a set menu -a safety valve as it were-in such an entrenched fashion that there is no possibility of a real disruption in the established systems of exploitation ${ }^{24}$. It is however, evident that the real world and the virtual world are not as mutually exclusive as they may seem. Social media outrage about an issue most certainly forces the authorities to take some action. A tribal farmers' protest march to Mumbai in the Spring of 2018 would have gone unnoticed but for the positive tweets and hash-tags of sympathy posted by the urban and otherwise aloof citizens of Mumbai that played a good part in forcing the government to accept the tribals' demands ${ }^{25}$. The government, judiciary, print media and the political leaders have all been forced to take notice of the subjects that trend on the social media. Virtual may not be so virtual after all. 


\section{Conclusion:}

The internet has been used by the Dalits in Maharashtra as an emancipatory space. With the help of the internet, they are getting access to authentic sources of information and an audience with a genuine interest in their stories. The internet helps them document their own history through their own gaze by bringing people together, protected by the comparative anonymity of cyberspace. These processes of course, come with a concomitant set of challenges. By connecting virtually, are the Dalits able to retain the connection with the grass-roots, the masses? After all, the Dalit movement was always known for its rootedness. Is it that the new media are creating a cultural hegemony of the digitally advantaged Dalits over the disadvantaged ones? Online catharsis might lead to a certain degree of distancing of Dalits from their own lived experiences and this may lead to an eventual apathy about real life events. And finally, while the internet can be a highly supervised and supervisable medium, there is a possibility that it may be used for socially engineering the opinions and activities of the Dalits. While the future holds the answers to many of these questions, from the point of historiography, one can see Voltaire's argument coming true. There is a slow but steady transition from a universe of Grand Narratives of Dalit history to a multiverse of competing memories and histories taking shape.

\section{Acknowledgments}

The author wishes to thank Professors Anne Feldhaus, Suhas Palshikar, Prachi Deshpande, Balasaheb Kambale and Anirudh Deshpande for their suggestions and scholar-activists Raju Kamble, Vaibhav Chhaya, Gaurav Somvamshi, and Sagar Naik for their review and comments on an earlier draft of the paper. 


\section{References}

1 Voltaire (François-Marie Arouet), Jeannotet Colin, Cramer, Geneva P. 101. Accessed on 10-012018.

https: / / books.google.co.in / books?id=mxFAAAAAcAAJ\&q=\%22fables+convenues\%22\&redir_e $\mathrm{sc}=\mathrm{y} \# \mathrm{v}=$ snippet $\& \mathrm{q}=\% 22 \mathrm{fables} \% 20$ convenues $\% 22 \& \mathrm{f}=$ false

2 The word Dalit in Sanskrit literally means crushed or trampled upon. This is a word used for the people of the formerly untouchable castes in South Asia. Many other words have been used to describe the same group of people, eg. Untouchables, Shudras, Pariahs, Depressed Classes, Harijans, etc. These nomenclatures are rejected for various reasons by the Dalits themselves. Even the word Dalit is not unchallenged as some prefer the name Ambedkarite.. I have stuck to Dalit here, primarily because of its widespread usage and acceptance.

3 'The Creators of the three Vedas are the Cunning, the Clever and the Night-wanderers.' Charvaka, quoted in Sayana Madhava's Savadarshanasamgraha, P. 14. Accessed on 10-01-2018. https://archive.org/details/Sarva-darsana-sangrahaOfMadhavacharya (translation mine.) Charvaka was one of the ancient Indian philosophers who negated the authority of the Vedas as repositories of knowledge.

4 Tukaram, ,Gatha, 2256. Accessed on 12-01-2018.

https://mr.wikisource.org/wiki/\%E0\%A4\%A4\%E0\%A5\%81\%E0\%A4\%95\%E0\%A4\%BE\%E0\% A4\%B0\%E0\%A4\%BE\%E0\%A4\%AE_\%E0\%A4\%97\%E0\%A4\%BE\%E0\%A4\%A5\%Е0\%A4\%BE/\% E0\%A4\%97\%E0\%A4\%BE\%E0\%A4\%A5\%E0\%A4\%BE_\%E0\%A5\%A8\%E0\%A5\%A7\%E0\%A5\%A 6\%E0\%A5\%A7_\%E0\%A4\%A4\%E0\%A5\%87_\%E0\%A5\%A8\%E0\%A5\%AA\%E0\%A5\%A6\%E0\%A5 \%A6 (Translation mine. ) Tukaram was a seventeenth century poet renowned for his humanistic ideas and progressive views.

5 For a detailed discussion about the SatyaShodhakSamaj's efforts at creation of an alternative history and culture, see- ShraddhaKumbhojkar, Denial of Centrality to Vedic Texts, in Willy Pfändtner\& David Thurfjell (eds), Postcolonial Challenges to the Study of Religion, Interreligiösarelationer. Uppsala: Swedish Science Press, 2008.

6 YochaiBenkler, co-director of the Berkman Center for Internet and Society, Interview at the e-G8 Summit, Paris, 30-05-2011. Accessed from https://www.cbsnews.com/news/g8-hails-powerof-the-internet-as-an-instrument-for-emancipation/ on 10-12-2017.

7 In 2014 , India had shown a $240 \%$ growth in the number of internet users in the previous five years. In 2015, the number of internet users in India was 259.88 million. In 2017, it grew to 331.77 million people. Source: Statista.com accessed from https://www.statista.com/statistics/292488/fastest-growing-internet-populations / and https://www.statista.com/statistics/255146/number-of-internet-users-in-india/ on 28-012018.

8 Delta MilayoNdou, Being online will not guarantee emancipation, in The Herald, 27-10,2016. Accessed from http:/ / www.herald.co.zw/being-online-will-not-guarantee-emancipation/ on $11-12-201$

9 https://web.archive.org/web/20050206045328/ http://www.columbia.edu:80/itc/mealac/pritchett/00ambedkar/timeline/1950s.html accessed 24-01-2018.

10 http://ambedkarmission.org/about-aim.html accessed on 24-01-2018.

11 http://www.pucl.org/major_reports/Report\%20on\%20Khairlanji\%20Massacre,\%202007-2.pdf accessed 10-11-2017.

12 The original Marathi saying goes - Baamnagharee livne, Mharagharee gaane.

13 https://www.youtube.com/watch?v=t0wVhY5XYVM accessed 28-01-2018. 
14 https://www.youtube.com/user/kadhirnilavan/about accessed on 20-01-2018.

15 https://www.statista.com/statistics/380559/number-of-mobile-facebook-users-in-india/ accessed 14-01-2018.

16 https://www.facebook.com/vaibhav.chaya accessed 01-02-2018.

17 http://www.lokmat.com/blog/aurangabad/one-one-pen-sketchy-youth-eyes-campaign/ Marathi news article describing the journey of the movement. accessed 13th April 2018

$18 \mathrm{http}: / /$ roundtableindia.co.in/ roundta3/index.php?option=com_content\&view=article\&id=9190 : seven-questions\&catid=119:feature\&Itemid=132 accessed 01-02-2018

19 Interview with Umesh Hattikat, December 2016.

20 Discussion with Prof. Aravind Deshpande, Historian of Literature. March 2001.

21 Kumbhojkar, Shraddha, Baby Kamble Yanche Vaicharik Yogdaan, in Paramarsh, January, 2018. Pune.

22 (https://www.mid-day.com/articles/facebook-group-takes-on-casteism-in-india-with-bollywoodmemes/16920179) accessed 21-04-2018.

23 http://www.thehindu.com/news/national/other-states/dalit-youth-killed-for-ambedkar-songringtone/article7232259.ece accessed 01-02-2018.

24 Personal email communication with sagarnaik4511@gmail.com on 27-04-2018.

25 https://www.scoopwhoop.com/mumbai-comes-out-in-support-of-farmer-march/\#.nsnrw3ryc 